Article

PEREIRA, G.R. ${ }^{1}$

COSTA, N.V. ${ }^{1 *}$

MORATELLI, G. ${ }^{1}$

RODRIGUES-COSTA, A.C.P. ${ }^{2}$

\section{Growth AND Development of Digitaria insularis Biotypes Susceptible and Resistant to Glyphosate}

\section{Crescimento e Desenvolvimento de Biótipos de Digitaria insularis Suscetível e} Resistente ao Glyphosate

\begin{abstract}
The study aimed to evaluate the growth and development of biotypes of Digitaria insularis susceptible and resistant to glyphosate. Samples of biotypes were collected in Western Paraná in Cascavel, one susceptible (24057'29.06" S and

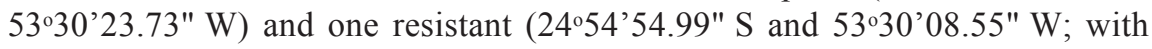
Resistance Factor of 2.96). The experiment was arranged in a completely randomized design with four replications. The treatments consisted of different plant collection timings, carried out at regular intervals of $14,21,28,35,42,49,56,63,70,77,84,91,98$, 105 and 112 days after emergence. The growth curve of susceptible and resistant biotypes were similar; however, the susceptible biotypes accumulated more leaf dry mass, while the resistant one accumulated more root dry mass. The resistant biotypes exhibited greater competitive efficiency and produced fewer tillers and inflorescences. The resistant biotype of $D$. insularis would have advantages over the original population of susceptible biotypes in an environment without application of glyphosate due to the low potential of aboveground biomass production and reproduction.
\end{abstract}

Keywords: growth analysis, chemical control, sourgrass, weeds.

RESUMO - Objetivou-se neste estudo avaliar o crescimento e desenvolvimento de biótipos de Digitaria insularis suscetivel e resistente ao glyphosate. Os biótipos avaliados foram coletados na região oeste do Paraná no município de Cascavel,

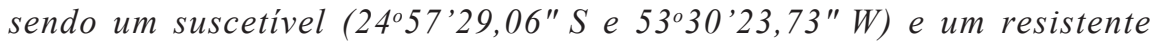

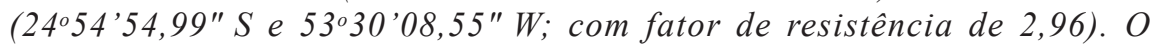
delineamento experimental utilizado foi delineamento inteiramente casualizado com quatro repetições. Os tratamentos foram constituídos por épocas de coletas das plantas, realizadas em intervalos regulares de 14, 21, 28, 35, 42, 49, 56, 63, 70, 77, 84, 91, 98, 105 e 112 dias após emergência. A curva de crescimento dos biótipos suscetivel e resistente foram semelhantes, porém o suscetivel acumulou mais massa seca de folha, enquanto o resistente acumulou mais massa seca de raizes. Os biótipos resistentes apresentaram maior eficiência competitiva e produziram menor quantidade de perfilhos e inflorescências. Considerando um ambiente sem a aplicação do glyphosate, o biótipo resistente de $\mathbf{D}$. insularis não teria vantagens em relação à população original de biótipos suscetíveis, devido ao baixo potencial de produção de biomassa da parte aérea e reprodutivo.

Palavras-chave: análise de crescimento, controle químico, capim-amargoso, plantas daninhas.
Received: March 21, 2016

Approved: June 10,2016

Planta Daninha 2017; v35:e017160505

1 Universidade Estadual do Oeste do Paraná, Centro de Ciências Agrárias, Marechal Cândido Rondon, Paraná, Brasil; ${ }^{2}$ Universidade Estadual de Maringá, Departamento de Ciências Agrárias, Umuarama, Paraná, Brasil. 


\section{INTRODUCTION}

Selecting for herbicide-resistant weed biotypes has been usual in agricultural lands in numerous countries; management practices used in modern agriculture based on intensive use of herbicides have increasingly urged the selection of these biotypes (Beckie and Reboud 2009; Vencill et al., 2012).

Farmers in the state of Paraná reported occurrence of glyphosate resistance in populations of Digitaria insularis (sourgrass) because its control has becoming extremely difficult and costly. This was corroborated by Licorini et al. (2015), who confirmed the occurrence of glyphosateresistant $D$. insularis biotypes in the Cascavel and Santa Mariana regions in western Paraná. Control of these biotypes has also been ineffective when recommended doses of clethodim (ACCase-inhibitor herbicide) are used, indicating occurrence of different tolerances to the herbicide and the need for adjustments in chemical management to prevent occurrence of multiple resistance.

The presence of individuals with distinct ability to tolerate the effects of herbicides on the population can also be an indication that these individuals have different adaptive and competitive abilities. Thus, biological/ecological behavioral studies on susceptible and resistant biotypes have become necessary in order to define specific management strategies for these species (Machado et al., 2006; Norsworthy et al., 2012).

When comparing glyphosate-susceptible and -resistant ryegrass (Lolium multiflorum) biotypes, it was found that tolerance extends the life cycle of the resistant biotype and reduces its ability to accumulate biomass and produce seeds (Vargas et al., 2005). However, it was not found a clear difference in the growth patterns of Bidens pilosa biotypes susceptible and resistant to ALS-inhibitor herbicides (Christoffoleti, 2001).

The growth pattern of $D$. insularis plants was investigated by Machado et al. (2006) and Marques et al. (2014). However, these authors did not compare the biological cycle of glyphosate-susceptible and resistant biotypes.

Therefore, the hypothesis of this study is based on the assumption that selecting for glyphosate-resistant $D$. insularis biotypes in Paraná croplands may change the species biology relative to the original population of susceptible biotypes. Also important is to know their growth habits in order to plan control measures accordingly.

The aim of this study was to evaluate the growth and development of glyphosate-tolerant and susceptible $D$. insularis biotypes.

\section{MATERIAL AND METHODS}

Suspected resistance-developing biotypes of Digitaria insularis were harvested in the western region of Paraná, in the municipality of Cascavel. The susceptible biotype (2457'29.06" S and $53^{\circ} 30^{\prime} 23.73^{\prime \prime} \mathrm{W}$ ) was collected from an area without a history of herbicide application, and the resistant biotype $\left(24^{\circ} 54^{\prime} 54.99^{\prime \prime} \mathrm{S}\right.$ and $\left.53^{\circ} 30^{\prime} 08.55^{\prime \prime} \mathrm{W}\right)$ from a farming land subjected to intensive use of glyphosate. Mature seeds of $50 \mathrm{D}$. insularis plants were harvested in each crop area.

Preliminarily, the resistance of tolerant-suspected biotype was determined, using an adaptation of the method proposed by Seefeldt et al. (1995). It was found that the resistant biotype had a 2.96 resistance factor (data not shown). This factor indicates that the glyphosate dose that is necessary to reduce $50 \%$ of dry matter production in the resistant biotype was 2.96 times higher than that necessary to reduce the same amount of dry matter in the susceptible biotype. For the analysis of the biotypes growth, a completely randomized experimental design with four replications was used. The treatments consisted of plants harvesting timings at regular intervals of $14,21,28,35,42,49,56,63,70,77,84,91,98,105$ and 112 days after emergence (DAE), corresponding to 15 harvest timings.

Seeds of the biotypes studied were planted in expanded polystyrene trays with 128 cells filled with a substrate formulated with composted pine bark, vegetable peat and vermiculite, on March 8 , 2014. Germination occurred seven days after seeding. The trays were watered three times/day to keep the substrate moist. 
The seedlings were transplanted 14 days after emergence to plastic pots with a capacity of $11 \mathrm{dm}^{-3}$ containing clayish soil, classified as dystrophic Red Latosol, previously fertilized as recommended for maize (Poaceae) basic fertilization, with $380 \mathrm{~kg} \mathrm{ha}^{-1}$ of formulated NPK 11-19-14 (Raij et al., 1997). Irrigations were performed on a daily basis to keep soil always moist.

Four supplementary foliage applications of the fertilizer were performed during the plants growth, at 35, 56, 77 and $98 \mathrm{DAE}$ of the plants, with application of $15 \mathrm{mg}$ of $\mathrm{N}, 5 \mathrm{mg}$ of $\mathrm{P}_{2} \mathrm{O}_{5}$ and $10 \mathrm{mg}$ of $\mathrm{K}_{2} \mathrm{O}$ per pot in each fertilization, as proposed by Machado et al. (2006).

Prior to any destructive evaluation, the number of tillers and inflorescences per plant was counted.

The collected leaves were scanned using a HP Deskjet 2546 scanner, 200 DPI resolution, and then processed by ImageJ software to obtain the leaf surface area (Santos et al., 2014).

Subsequently, the biotypes aboveground and root dry matter $(\mathrm{g})$ were determined after drying in forced air oven at $65{ }^{\circ} \mathrm{C}$ to constant mass. The total dry matter of the plants was obtained by the sum of the aboveground mass (leaves and stem) and root mass.

Based on the leaf surface area and dry matter values, for each evaluation period the Absolute Growth Rate (AGR), Liquid Assimilation Rate (LAR), and the Relative Growth Rate (RGR) were determined, according to the method suggested by Benincasa (2003).

Data relating to the number of tillers, number of inflorescences, leaf surface area, leaf, stem, root and total dry matter, in addition to the growth analysis data, were subjected to regression analysis. The model was chosen taking into account the biological phenomenon logic, normality, significance of regression and the high coefficient of determination.

\section{RESULTS AND DISCUSSION}

The susceptible biotype of Digitaria insularis exhibited a greater number of tillers per plant when compared to the resistant biotype througout the biotypes development period (Figure 1). At the end of the cycle, the susceptible and resistant biotypes exhibited an average number of 34.29 and 29.13 tillers per plant, respectively.

The reproductive phase of both biotypes began at the same time (70 DAE), but the susceptible biotype plants produced $32.4 \%$ more inflorescences per day than the resistant biotype plants (Figure 2). These results show that the selection of glyphosate-resistant biotypes may reduce

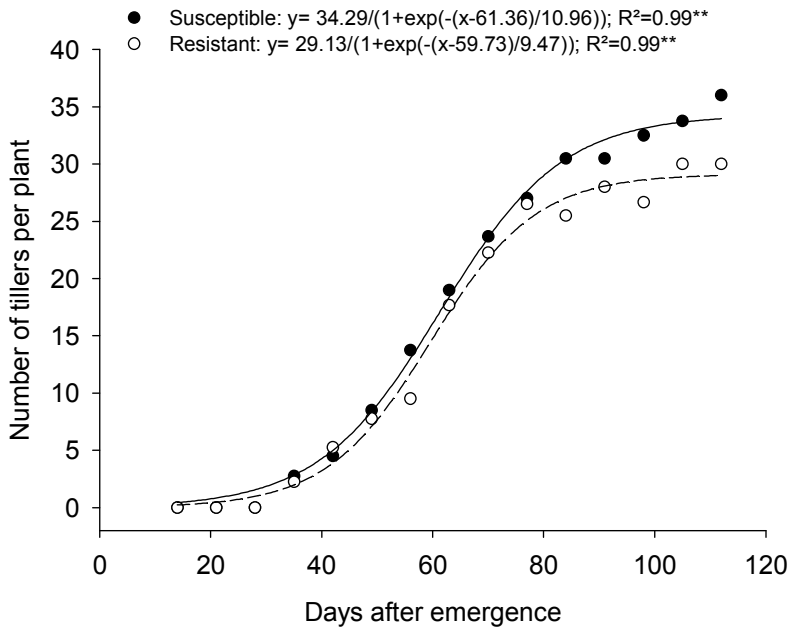

** significant at $1 \%$ probability level by the $\mathrm{F}$ test.

Figure 1 - Number of tillers during the development of glyphosate susceptible and resistant biotypes of Digitaria insularis.

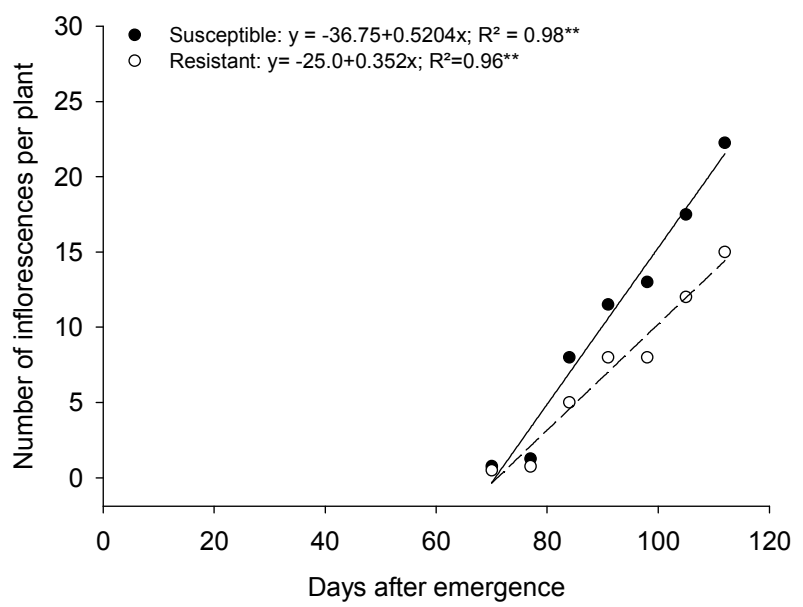

** significant at $1 \%$ probability level by the $\mathrm{F}$ test.

Figure 2 - Number of inflorescences during the development of glyphosate susceptible and resistant biotypes of Digitaria insularis. 
the reproductive potential of $D$. insularis plants. Similarly, Vargas et al. (2005) found that glyphosate-susceptible biotypes of Lolium multiflorum produced 38.8 and $54.2 \%$ more tillers and seeds, respectively, than the resistant biotype.

Data on the leaf surface area of both $D$. insularis biotypes showed that they had a similar growth rate until $112 \mathrm{DAE}$ (Figure 3). At the end of cycle, the maximum accumulation of leaf dry matter of the susceptible biotype was $29.53 \%$ greater than that obtained by the resistant biotype (Figure 4). It was not possible to observe differences between the biotypes as to the accumulation of stem dry matter (Figure 5), but the accumulated root dry matter of the resistant biotype was $21.8 \%$ greater than that accumulated by the susceptible biotype (Figure 6). This fact shows the different morphological features developed by the biotypes. The susceptible biotype has more tillers, inflorescences and thicker leaves, which result in more weight, while the resistant one exhibited more ability in exploiting and searching for soil zones containing the required nutrients. Likewise, the lower accumulation of leaf dry matter by the resistant biotype can be explained by the smaller number of tillers produced.

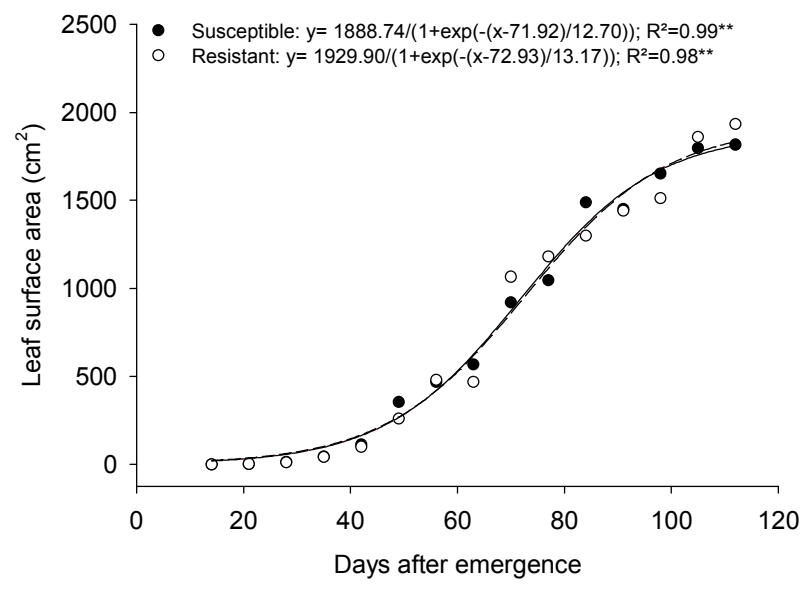

** significant at $1 \%$ probability level by the $\mathrm{F}$ test.

Figure 3 - Leaf surface area during the development of glyphosate susceptible and resistant biotypes of Digitaria insularis.

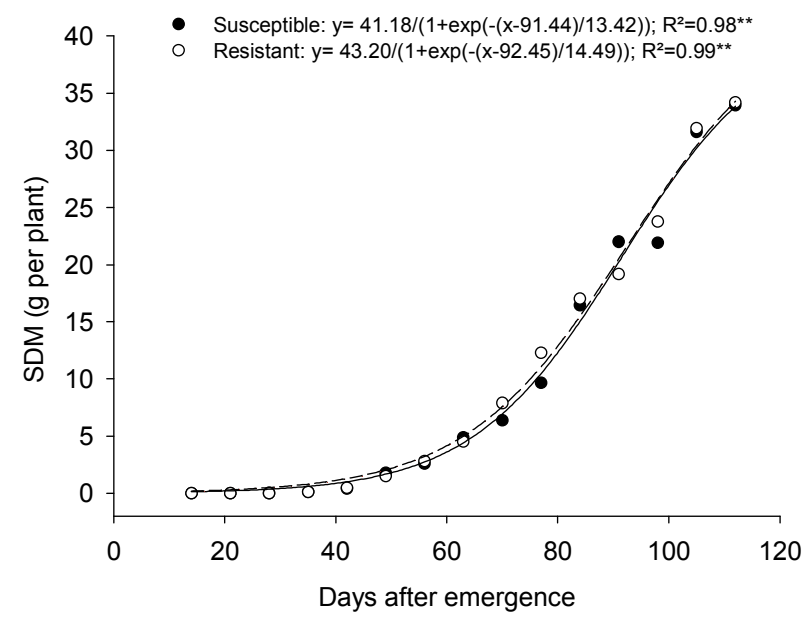

** significant at $1 \%$ probability level by the $\mathrm{F}$ test.

Figure 5 - Stem dry mater (SDM) during the development of glyphosate susceptible and resistant biotypes of

Digitaria. insularis.

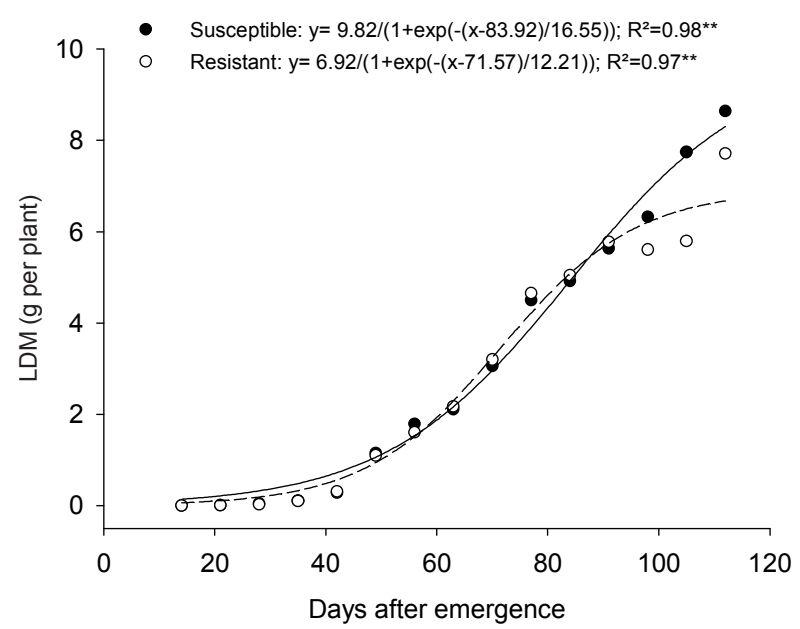

** significant at $1 \%$ probability level by the $\mathrm{F}$ test.

Figure 4 - Leaf dry matter (LDM) during the development of glyphosate susceptible and resistant biotypes of

Digitaria insularis.

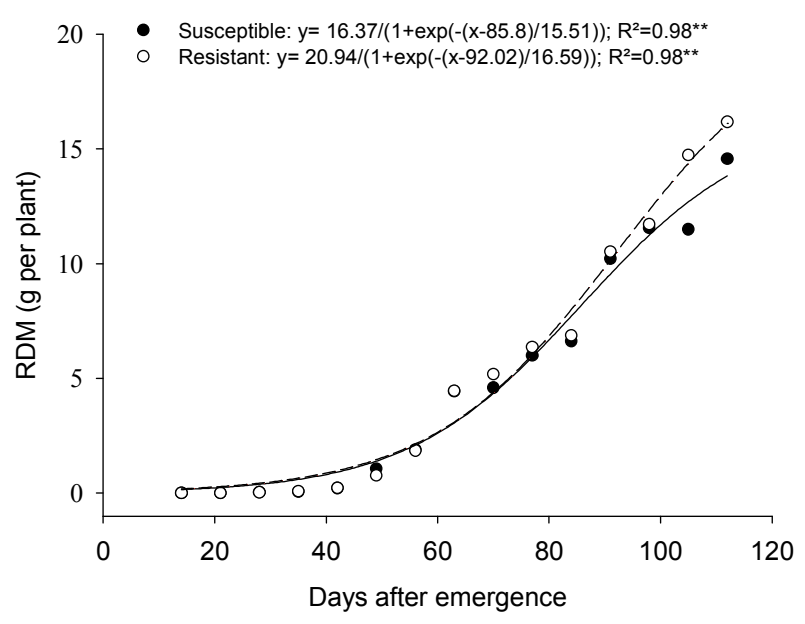

** significant at $1 \%$ probability level by the $\mathrm{F}$ test.

Figure 6 - Root dry matter (RDM) during the development of glyphosate susceptible and resistant biotypes of

Digitaria insularis. 
The differences found between the biotypes for accumulated leaf dry matter and root dry matter suggest that there might have occurred a compensatory effect on the determination of the plants' total dry matter, since the total accumulation values of both biotypes were similar throughout the lifecycle (Figure 7).

The susceptible and resistant biotypes exhibited a total maximum accumulated dry matter around 71.6 and 69.3 g per plant, respectively, at 112 DAE. These results corroborate those obtained by Marques et al. (2014) in D. insularis plants without distinction of glyphosate resistance. However, in the study conducted by Machado et al. (2006), a slow growth rate was observed until $45 \mathrm{DAE}$, and the maximum accumulated total dry matter of $D$. insularis was $30.7 \mathrm{~g}$ per plant at 105 DAE. These authors also suggest the possibility of a good cultural control of this species by cultures that have a fast initial growth, large leaf surface area and cover the ground rapidly. Such variations in the results can be due to the environmental conditions during the experiment as well as the innate genetic diversity of the weed species used.

AGR provides an estimate of the plants' mean growth velocity during the development cycle. Initially, the susceptible biotype exhibited a higher growth velocity, $30 \%$ higher than the resistant biotype (Figure 8). This result indicates that the susceptible biotype is able to cover the soil surface more rapidly than the resistant one until 49 DAE. Likewise, at the end of the cycle, the susceptible biotype had an AGR 13.0\% higher than the resistant biotype.

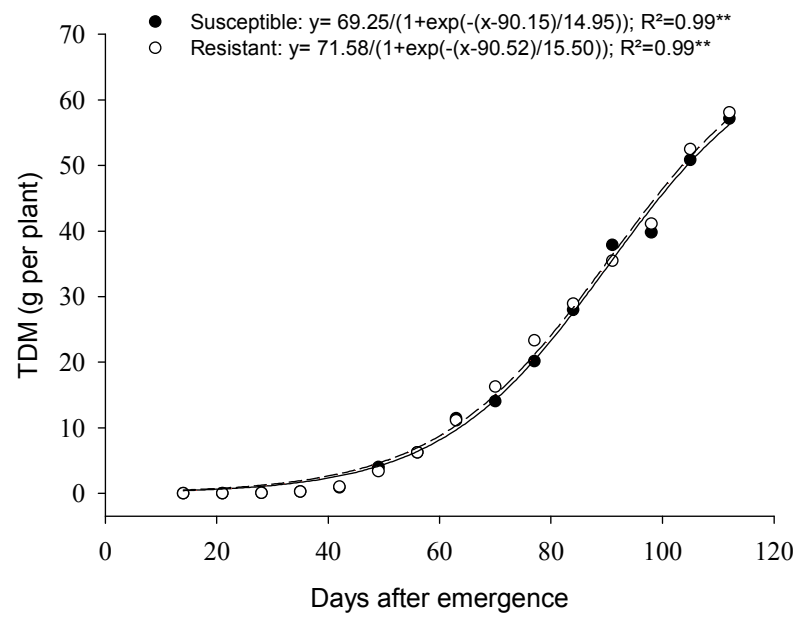

** significant at $1 \%$ probability level by the $\mathrm{F}$ test.

Figure 7 - Total dry matter (TDM) during the development of glyphosate susceptible and resistant biotypes of

Digitaria insularis.

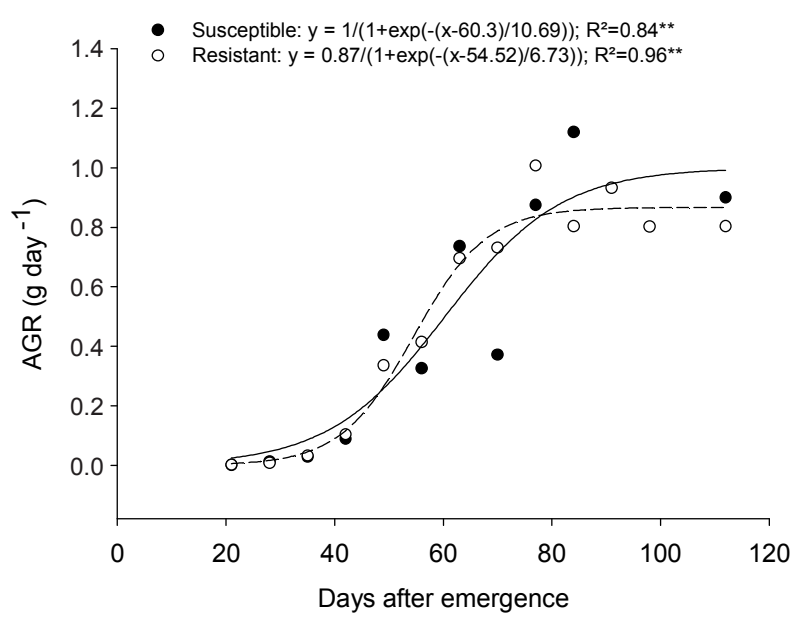

** significant at $1 \%$ probability level by the $\mathrm{F}$ test.

Figure 8 - Absolute growth rate (AGR) of glyphosate susceptible and resistant biotypes of Digitaria insularis suscetível.

It was not possible to adjust the data to a model for the LAR of the susceptible biotype (Figure 9). The LAR decreased during the resistant biotype development, indicating a higher photosynthetic capacity at the plant's early stages of development. It can be inferred that from $40 \mathrm{DAE}$, when the plants increase their leaf size and accelerate growth, there is occurrence of self-shading and, consequently, a decrease of liquid photosynthesis, with direct effects on the LAR.

The RGR indicates an increase in dry matter per unit of initial weight for a given time interval (Benincasa, 2003). The results demonstrated maximum RGR for both biotypes in the early growth stage (30 DAE); after this period, there was a progressive decline until completion of the cycle (Figure 10). However, the resistant plants reached maximum RGR in the early growth stage, $15 \%$ higher than the susceptible species.

This result corroborate the AGR data, given that the resistant biotype spends less energy to maintain a small amount of biomass produced, and the plant tends to be more efficient in producing daily more biomass per gram of biomass initially accumulated by the plant.

Christoffoleti (2001) found the same biomass production efficiency at the end of the cycle for susceptible and resistant biotypes of Bidens pilosa to ALS-inhibitor herbicides. However, this 


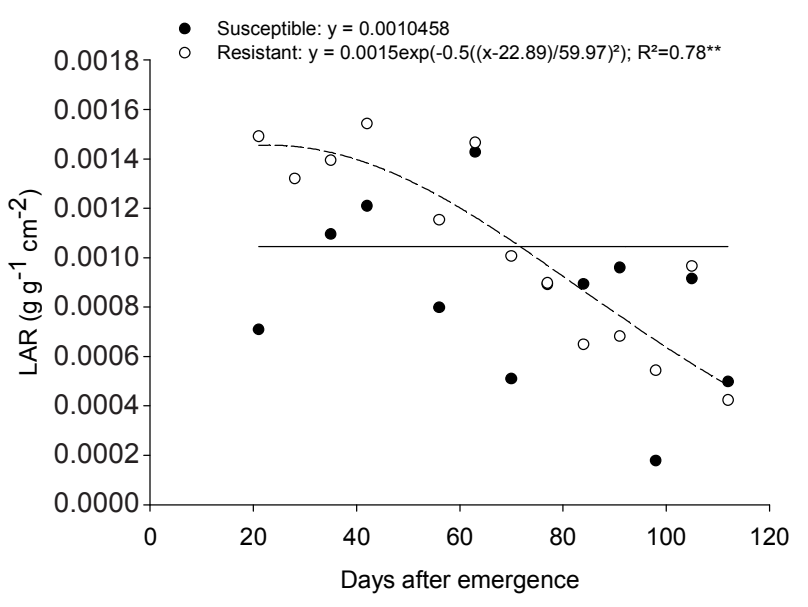

** significant at $1 \%$ probability level by the $\mathrm{F}$ test.

Figure 9 - Liquid assimilation rate (LAR) of glyphosate susceptible and resistant biotypes of Digitaria insularis.

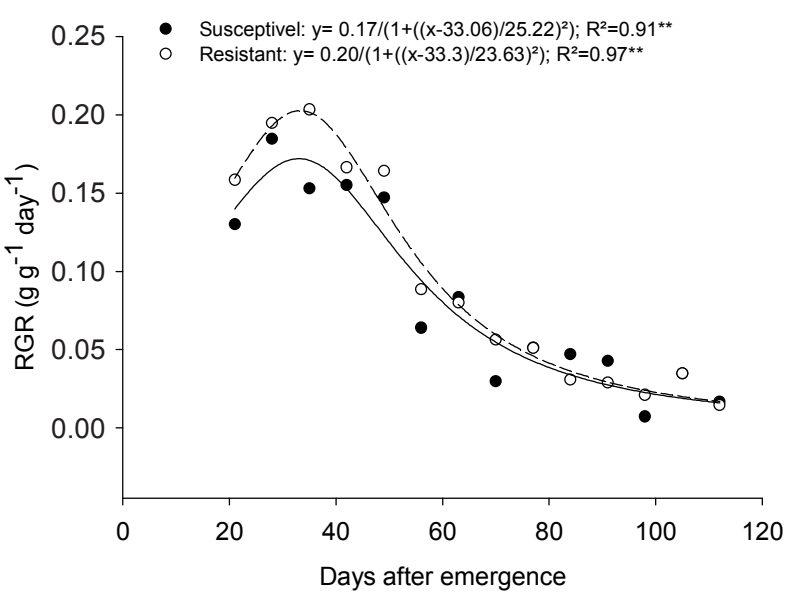

** significant at $1 \%$ probability level by the $\mathrm{F}$ test.

Figure 10 - Relative growth rate (RGR) of glyphosate susceptible and resistant biotypes of Digitaria insularis.

author explains that the higher RGR of the resistant biotype compensates for its smaller initial size, so that at the end of the cycle both biotypes had the same size.

In this experiment, the differences in the RGR indicate that the resistant biotypes of $D$. insularis have greater competitive efficiency than the susceptible ones. Thus, the resistant biotype would have an advantage in the competition with susceptible biotypes, when cultivated without application of glyphosate.

It is worth noting that the greater reproductive capacity of the susceptible biotypes represents an evolutionary innate characteristic of aggressiveness to dominate the environment and perpetuate the species and, consequently, suppress the development of slow-growing species. Therefore, selecting for glyphosate-resistant biotypes of $D$. insularis has adverse impacts on the plants' growth and development ability, but absence of competition with the susceptible (more adapted) biotype and the ability to persist after chemical management may favor the dissemination in the resistant biotype environment (Vargas et al., 2005).

Therefore, it is clear the importance of employing integrated weed management strategies in croplands to prevent not only weed interference in the development and management of cultures but also the selection for herbicide-resistant biotypes, so that the useful life of these products can be increased (Vila-Aiub et al., 2008; Carvalho et al., 2011; Gemelli et al., 2012; Norsworthy et al., 2012).

It is also worth noting that the differences in growth and in the phenological development of glyphosate-resistant and susceptible biotypes of $D$. insularis can be determined and estimated through mathematical models. These models can be used to understand the influence of biological, ecological, genetic and management factors on the likelihood of selection for glyphosate-resistant weeds in agricultural lands and in the development of strategies to mitigate these risks by means of simulation models (Neve, 2008; Marques et al., 2014).

The resistant biotypes have greater competitive efficiency (> RGR) and greater accumulation of root dry matter, but produce fewer tillers and inflorescences. The resistant biotype of $D$. insularis would not be advantageous compared to the original population of susceptible biotypes in an environment without glyphosate application, due to the low potential of biomass production in the aboveground part of the plant and reproductive ability.

\section{REFERENCES}

Beckie H.J., Reboud X. Selecting for weed resistance: herbicide rotation and mixture. Weed Technol. 2009;23:363-70.

Benincasa M.M.P. Análise de crescimento de plantas - noções básicas. Jaboticabal: FUNEP, 2003. 41p. 
Carvalho L.B. et al. Detection of sourgrass (Digitaria insularis) biotypes resistant to glyphosate in Brazil. Weed Sci. 2011;59:171-6.

Christoffoleti P.J. Análise comparativa do crescimento de biótipos de picão-preto (Bidens pilosa) resistente e suscetível aos herbicidas inibidores da ALS. Planta Daninha. 2001;19:75-83.

Gemelli A. et al. Aspectos da biologia de Digitaria insularis resistente ao glyphosate e implicações para o seu controle. Rev Bras Herbic. 2012;11:231.

Licorini L.R. et al. Identificação e controle de biótipos resistentes de Digitaria insularis (L.) Fedde ao glyphosate. Rev Bras Herbic. 2015;14:141-7.

Machado A.F.L. et al. Análise de crescimento de Digitaria insularis. Planta Daninha. 2006;24:641-7.

Marques B.S. et al. Growth and development of sourgrass based on days or thermal units. Planta Daninha. 2014;32:483-90.

Neve P. Simulation modelling to understand the evolution and management of glyphosate resistance in weeds. Pest Manage Sci. 2008;64:392-401.

Norsworthy J.K. et al. Reducing the risks of herbicide resistance: best management practices and recommendations. Weed Sci. 2012;60:31-62.

Raij B. van et al. Recomendações de adubação e calagem para o Estado de São Paulo. 2a.ed. Campinas: IAC, 1997. 285p. (Boletim técnico, 100)

Santos S.N. et al. Análise comparativa de métodos de determinação de área foliar em genótipos de cacau. Biosci J. 2014;30:411-9.

Seefeldt S.S., Jensen J.E., Fuerst E.P. Log-logistic analysis of herbicide dose-response relationships. Weed Technol. 1995;9:218-27.

Vargas L. et al. Alteração das características biológicas dos biótipos de azevém (Lolium multiflorum) ocasionada pela resistência ao herbicida glyphosate. Planta Daninha. 2005;23:153-60.

Vencill W.K. et al. Herbicide resistance: toward an understanding of resistance development and the impact of herbicide-resistant crops. Weed Sci. 2012;60:2-30.

Vila-Aiub M.M. et al. Glyphosate-resistant weeds of South American cropping systems: an overview. Pest Manage Sci. 2008;64:366-71. 